\title{
Geodetic mass balance of Azarova glacier, Kodar mountains, eastern Siberia, and its links to observed and projected climatic change
}

\author{
M. SHAHGEDANOVA, ${ }^{1}$ V. POPOVNIN, ${ }^{2}$ A. ALEYNIKOV, ${ }^{2}$ C.R. STOKES ${ }^{3}$ \\ ${ }^{1}$ Department of Geography and Walker Institute for Climate System Research, University of Reading, Whiteknights, \\ PO Box 227, Reading RG6 6AB, UK \\ E-mail: m.shahgedanova@reading.ac.uk \\ ${ }^{2}$ Department of Cryolithology and Glaciology, Faculty of Geography, Moscow State University, Leninskiye Gory, \\ 119992 Moscow, Russia \\ ${ }^{3}$ Department of Geography, Durham University, South Road, Durham DH1 3LE, UK
}

\begin{abstract}
The Kodar mountains in eastern Siberia accommodate 30 small, cold-based glaciers with a combined surface area previously estimated at $\sim 19 \mathrm{~km}^{2}$. Very little is known about these glaciers, which were first surveyed in the late 1950s. In this paper, we use terrestrial photogrammetry to calculate changes in the surface area, elevation, volume and geodetic mass balance of Azarova glacier between 1979 and 2007 and relate these to meteorological data from nearby Chara weather station (1938-2007). The glacier surface area declined by $20 \pm 6.9 \%$ and the surface lowered by an average of $20 \pm 1.8 \mathrm{~m}$ (mean thinning $0.71 \mathrm{~m} \mathrm{a}^{-1}$ ), resulting in a strongly negative cumulative and average mass balance of $-18 \pm 1.6 \mathrm{~m}$ w.e. and $-640 \pm 60 \mathrm{~mm}$ w.e. $\mathrm{a}^{-1}$, respectively. The July-August air temperature increased at a rate of $0.0366^{\circ} \mathrm{Ca}^{-1}$ between 1979 and 2007 , and the 1980-2007 period was on average $\sim 1{ }^{\circ} \mathrm{C}$ warmer than 1938-79. In comparison to the 1961-90 period, regional climate projections for the A2 and $\mathrm{B}^{2} \mathrm{CO}_{2}$ emission scenarios developed using the PRECIS regional climate model indicate that summer temperatures will increase by $2.6-4.7^{\circ} \mathrm{C}$ and $4.9-6.2^{\circ} \mathrm{C}$, respectively, during the 2071-2100 period. The annual total of solid precipitation will increase by $20 \%$ under the $\mathrm{B} 2$ scenario but is projected to decline by $3 \%$ under the A2 scenario. Azarova glacier exhibits high sensitivity to climatic warming due to its low elevation and exposure to comparatively high summer temperatures. Further summer warming and a decline in solid precipitation projected under the A2 scenario will force Azarova glacier to retreat further, but the impact of an increase in solid precipitation projected under the B2 scenario is more uncertain and requires further investigation before a more conclusive prediction can be made.
\end{abstract}

\section{INTRODUCTION}

The progressive shrinkage of temperate and polythermal glaciers located in the maritime regions in response to the climatic warming of the 20th century has been widely reported (e.g. Barry, 2006). Less is known about cold-based glaciers located in continental interiors. These regions are characterized by extremely low air temperatures and precipitation in the cold, 'climatically dormant' season, and by the fact that accumulation and ablation can occur simultaneously in summer. These glaciers form mostly through refreezing of meltwater that prevents mass loss in the accumulation zone (Preobrazhensky, 1960). To date, most research on the mass balance and shrinkage of cold-based glaciers has focused on the high-elevation glaciers of the Tibetan Plateau, many of which are influenced by the monsoon. These studies show that the Tibetan glaciers characterized by summer accumulation are likely to be more sensitive to climatic warming than glaciers dominated by a winter accumulation regime (Fujita and Ageta, 2000; Fujita, 2008). However, very little is known about the response of the cold-based Siberian glaciers located at lower elevations.

In Siberia, glacial research has focused mainly on the Altai mountains, where a significant decline in mass balance and surface area of glaciers has been reported between the 1950s and 2000s, but these glaciers grow mostly through accumulation in April-May and SeptemberOctober (Kadota and Gombo, 2007; Shahgedanova and others, 2010). In the Suntar-Khayata, northeastern Siberia, Ananicheva (2006) reported glacier shrinkage of 19\% between 1973 and 2003, with a negative average annual specific mass balance of $206 \mathrm{~mm}$ w.e. measured for glacier No. 31 (1957-2001) using geodetic methods. In contrast, Gurney and others (2008) suggested a more subdued retreat of glaciers in the Buordakh massif, Chersky mountains, northeastern Siberia. These glaciers lost $17 \%$ of their surface area between 1850 and 2000, comparable to values reported by Solomina (2000) for Chersky, Kodar and Suntar-Khayata. No other mass-balance measurements are available in Siberia (outside the Altai). The paucity of assessments of glacier change and the regional variability of rates that have been measured necessitate further research into the behaviour of cold-based Siberian glaciers that gain their mass through meltwater refreezing.

One area that has evaded detailed scrutiny is the Kodar mountains. The Kodar glaciers were first mentioned in travellers' reports in 1883 but were not examined in any detail until 1958 when Preobrazhensky (1960) catalogued 30 glaciers with a combined area of $15 \mathrm{~km}^{2}$. Later analysis of aerial photographs from 1963 confirmed the existence of 30 glaciers with a combined surface area of $18.8 \mathrm{~km}^{2}$ (Novikova and Grinberg, 1972; World Glacier Inventory (WGI), http:// nsidc.org/data/glacier_inventory/). The remote location constrained further glaciological research in the Kodar, although a 1:10000 map of Azarova glacier was produced in 1979 


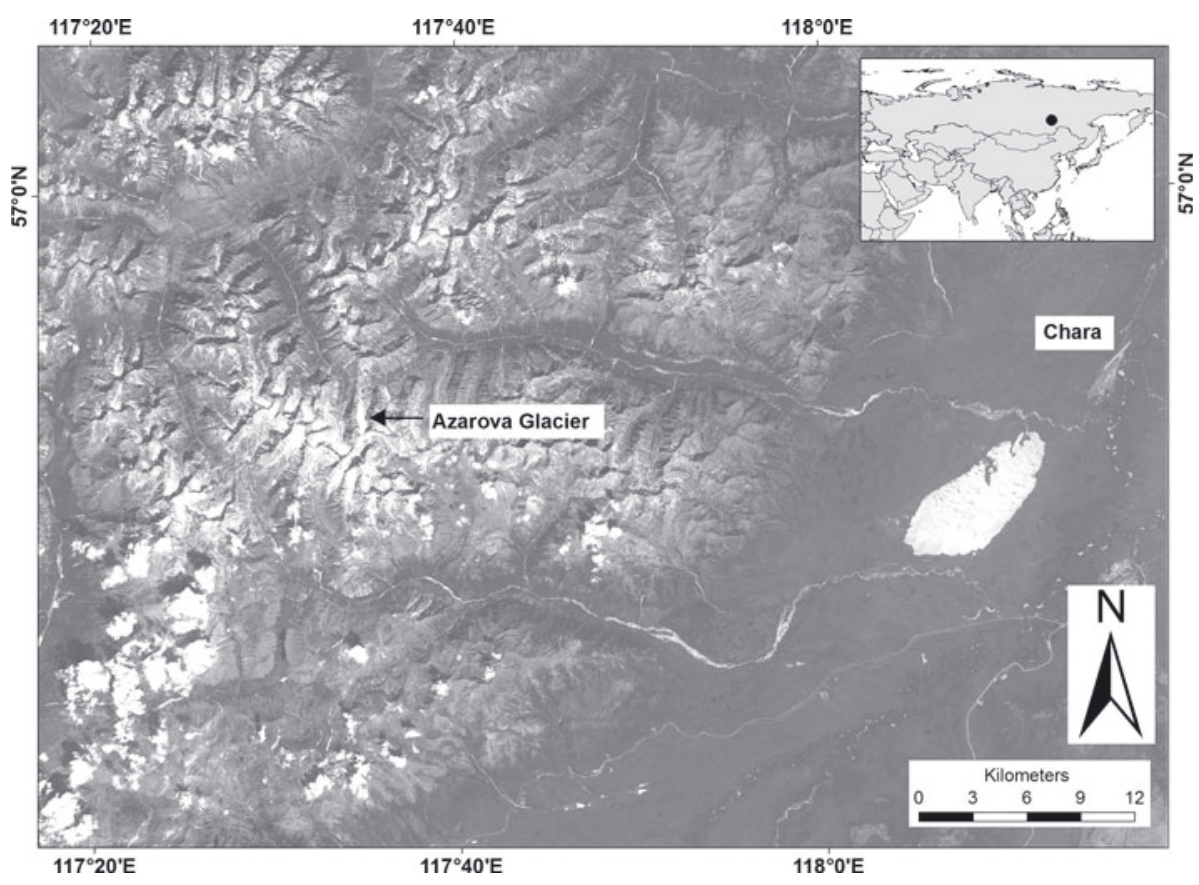

Fig. 1. Location map. Landsat Enhanced Thematic Mapper (ETM) imagery of the Kodar mountains containing 30 small mountain-valley and cirque glaciers is used as background.

from a theodolite survey by V.M. Plyusnin (unpublished; Irkutsk Institute of Geography, Russian Academy of Sciences).

This paper presents results of more recent geodetic measurements of Azarova glacier (in 2007) and links these to both local and regional climate data. The objectives are: (1) to assess changes in the surface area and elevation of Azarova since 1979 using terrestrial photogrammetry; (2) to estimate the geodetic mass balance of Azarova for the 19792008 period; (3) to relate the observed glacier changes to climatic variation; and (4) to present future regional climatechange scenarios and discuss their possible implications for the Kodar glaciers.

\section{STUDY AREA}

The Kodar mountains are located at $56^{\circ} 45^{\prime}-57^{\circ} 15^{\prime} \mathrm{N}$, $117-118^{\circ} \mathrm{E}$ (Fig. 1). The elevations range between 1500

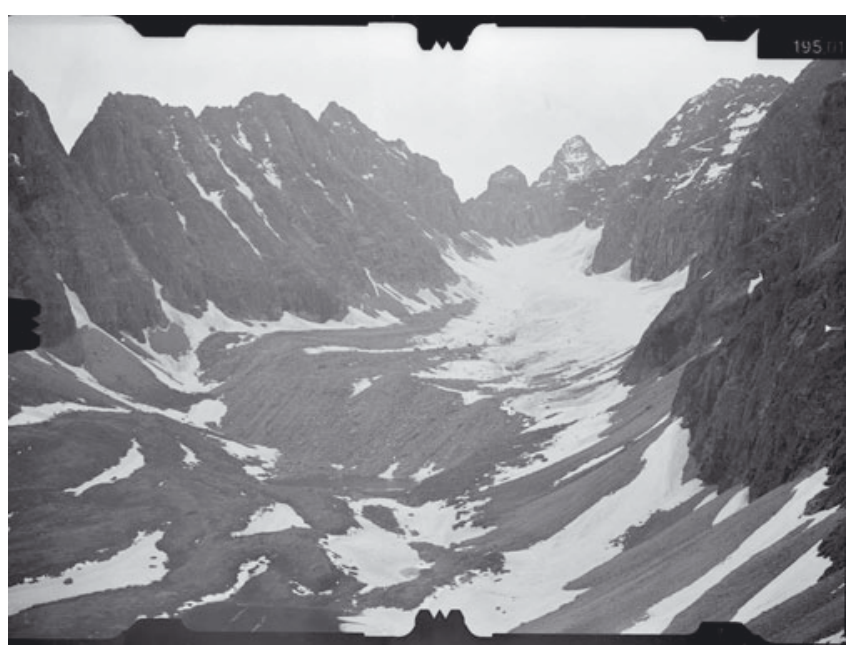

Fig. 2. Photograph of Azarova glacier taken during the phototheodolite survey in August 2007. and $2900 \mathrm{ma}$ a.s.l., and the highest elevation is $3072 \mathrm{~m}$. Glaciers are positioned mainly between 2000 and $2700 \mathrm{~m}$ a.s.I. The WGI (http://nsidc.org/data/glacier_inventory/) classifies 16 glaciers as cirque, 6 as mountain-valley, 3 as cirque-valley and 5 as niche glaciers. Sixty per cent of the glaciers face north and northeast. Azarova glacier is the second largest in the Kodar and is the focus of this study. It is a north-facing mountain-valley glacier located at $56.889^{\circ} \mathrm{N}$, $117.577^{\circ} \mathrm{E}$ and extending from $2480 \mathrm{~m}$ down to $2145 \mathrm{~m}$ a.s.l. (Fig. 2). In 2007, its area was $0.56 \mathrm{~km}^{2}$ with a length of $1.7 \mathrm{~km}$ (there are no tributaries). Avalanche nourishment from the steep valley sides predetermines an asymmetric structure of the glacier, with its surface sloping down the valley from west to east. Located in front of the glacier is an area of 'dead ice' covered by moraine deposits. The area is characterized by continuous permafrost with $\sim 60 \%$ ice content (Preobrazhensky, 1960).

The regional climate is characterized by extreme continentality (Shahgedanova, 2002). The continentality index, defined as the range between the average temperatures of the warmest and coldest months of the year, is 50 . The region is dominated by the Siberian high between November and March. At the Chara meteorological station, located $50 \mathrm{~km}$ to the southeast $\left(56.92^{\circ} \mathrm{N}, 118.37^{\circ} \mathrm{E} ; 711 \mathrm{~m}\right.$ a.s.l.; Fig. 1), the mean monthly air temperatures from November to March range from $-18{ }^{\circ} \mathrm{C}$ to $-33^{\circ} \mathrm{C}$; and the seasonal precipitation total for this cold period accounts for only $5 \%$ of the annual total of $356 \mathrm{~mm}$ (Fig. 3). The Siberian high develops in the lowest 2000-2500 m and is replaced by a trough of low pressure aloft, which results in a decoupling between the processes occurring in the lower and the middle atmospheres. In winter, both air temperature and precipitation increase with altitude (Panagiotopoulos and others, 2005).

Regular meteorological measurements have never been conducted in the Kodar, but those from individual years indicate that snowfalls occur throughout the year, and about $80 \%$ of solid precipitation occurs in late spring and early 
autumn (Novikova and Grinberg, 1972). Glaciers accumulate mass predominantly through water refreezing (Preobrazhensky, 1960). The ablation season, during which the formation of ice also occurs, is limited to July-August (Novikova and Grinberg, 1972). Although the melt season is short, summer temperatures are comparatively high, and at the Chara station the mean July air temperature is $16^{\circ} \mathrm{C}$.

\section{DATA AND METHODS}

\section{Calculation of surface area, elevation and geodetic mass balance}

Widely used until the 1950s, ground-based photogrammetry surveys have gradually been superseded by aerial photography and, more recently, by both satellite and airborne remote sensing (e.g. Andreassen, 1999; Arendt and others, 2002; Bauder and others, 2007; Thibert and others, 2008). However, ground-based photogrammetry remains an accurate tool and can provide a very useful comparison with historical surveys to estimate glacier change. Neither aerial photographs from 1963 nor more recent aerial imagery suitable for assessing glacier volume change are available for the Kodar mountains. However, the data from the August 1979 survey were made available and this survey was repeated in August 2007 using the same control points (CPs) and baselines as in 1979. This enabled an estimation of changes in the area and surface elevation of Azarova glacier and its geodetic mass balance for the 1979-2007 period. Indeed, the geodetic method of mass-balance measurement is considered to be more accurate over longer time periods than the short-term glaciological method using stake measurements (Cox and March, 2004; Cogley, 2009). Use of the direct glaciological method is also complicated on glaciers that gain mass through refreezing of meltwater (Fujita and Ageta, 2000). The two consecutive surveys therefore provided a unique opportunity to assess glacier volume change and mass balance on one of the Kodar glaciers, and represent the only available mass-balance record for this region.

Changes in the surface area and elevation of Azarova glacier were estimated as follows: (1) a photo-theodolite survey of the glacier was conducted in July-August 2007; (2) a map and a digital elevation model (DEM) of the glacier were developed using the results of the 2007 survey; (3) a DEM was derived from the 1979 map; (4), changes in surface area and surface elevation and volume were inferred from a comparison of the 1979 and 2007 maps and DEMs respectively; and (5) geodetic mass balance, $G$, was calculated using Equation (1), from Cogley (2009):

$$
G=\frac{\bar{\rho} \overline{\Delta h}}{\Delta t}
$$

where $\bar{\rho}$ is ice density $\left(\mathrm{kg} \mathrm{m}^{-3}\right), \overline{\Delta h}$ is the change in glacier surface elevation averaged over the glacier surface, and $\Delta t$ is the 1979-2007 time span. The variable $\overline{\Delta h}$ was averaged over the mean of 1979 and 2007 glacier surface areas following Thibert and others (2008). Volume changes were calculated for the common glaciated areas covered by the 1979 and 2007 DEMs and include ice that had disappeared altogether (Bauder and others, 2007).

The photo-theodolite survey used two pairs of groundbased photographic images of Azarova glacier from the same two baselines that were used in 1979 (Fig. 2). Two

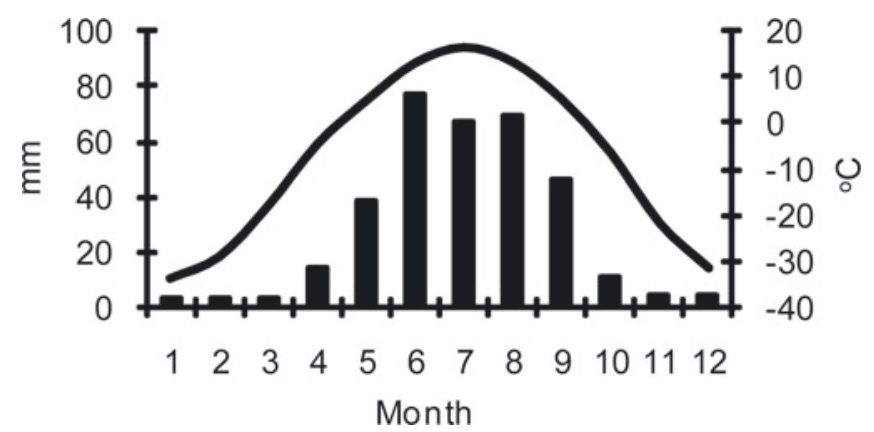

Fig. 3. Monthly climatologies of air temperature (1938-2007; curve) and precipitation (1952-2007; columns) for the Chara meteorological station.

baselines were considered sufficient because of the very simple shape of the glacier and the good visibility of its entire surface (Fig. 2). A local geodetic network of 55 CPs was established using topographic features on the stable terrain around the glacier. Seventeen of the CPs were used in both 1979 and 2007 and were used as tie points for a relative control and co-registration of the 1979 and 2007 maps and DEMs. The CPs located on stable terrain were used to calculate root-mean-square errors (RMSE). RMSE $E_{x, y}$ of their positions for 1979 and 2007 was $\pm 2.4 \mathrm{~m}$.

A 1:10000 scale map of Azarova glacier with $10 \mathrm{~m}$ equidistant contours was produced from the 2007 survey using a stereo-autograph. The 1:10 000 map from 1979 with $10 \mathrm{~m}$ equidistant contours was digitized manually with an average horizontal deviation of $\pm 0.3 \mathrm{~mm}$ on the map, which is $\pm 3 \mathrm{~m}$ on the ground. Changes in the surface area of Azarova were estimated by the superimposition and subtraction of the two maps. Digitized contours of the surrounding area were superimposed where possible.

Two DEMs for 1979 and 2007 were developed from the maps using ArcView 3.2 software. Elevations were interpolated on regular grids with a resolution of $5 \mathrm{~m}$ using the kriging method. The $5 \mathrm{~m}$ grid spacing was found to be optimal for co-registration of DEMs, in line with the recommendations by Cox and March (2004) for calculating geodetic mass balance. Changes in elevation of the glacier surface were derived by subtracting the 2007 elevation data from the 1979 data for individual cells of the regular grids and averaging for different elevation zones and for the entire glacier.

It was assumed that changes in elevation were due to loss of ice with a constant density of $900 \mathrm{~kg} \mathrm{~m}^{-3}$, which is used in the majority of geodetic mass-balance calculations (Andreassen, 1999; Arendt and others, 2002; Cogley, 2009). Zemp and others (2010) commented that this assumption often leads to overestimation of mass balance due to changes in snow and firn layers. However, we consider this assumption realistic for Kodar glaciers where ice formation through refreezing is dominant and, as a result, firn content is minimal (Preobrazhensky, 1960).

\section{Quantification of error}

The accuracy of the estimation of surface area and elevation changes depends on (1) errors in triangulation and map and DEM construction; (2) comparison of two maps and DEMs; (3) delineation of glacier boundaries; and (4) seasonality in glacier thickness change (Sapiano and others, 1998; Andreassen, 1999; Arendt and others, 2002; Thibert and others, 2008). 
The planimetric error resulted from (1) errors in triangulation and co-registration of the 1979 and 2007 maps, and (2) errors in glacier boundary delineation due to the presence of snow and, more importantly, debris cover. Term (1) was calculated as the root sum square of $\mathrm{RMSE}_{x, y}$ $( \pm 2.4 \mathrm{~m})$ of the 1979 and 2007 tie-point locations and errors resulting from digitization of contours on both maps ( $\pm 3 \mathrm{~m}$ on the ground), giving a total of $\pm 4.8 \mathrm{~m}$. To express this error term as a percentage of glacier area, a buffer $4.8 \mathrm{~m}$ wide was created along the 1979 and 2007 glacier outlines (Granshaw and Fountain, 2006). The error term was calculated as an average ratio between the original 1979 and 2007 area and the areas with an increment of $4.8 \mathrm{~m}$, yielding an error of $5.7 \%$. Both the 1979 and 2007 surveys were conducted in August, in the second half of the ablation season. In 2007, the glacier tongue was free of seasonal snow which remained along the shaded glacier margins at higher elevations only. The uncertainty due to the presence of snow was resolved by mapping glacier boundaries from the Earth Resources Observation Systems EROS-B satellite image with a resolution of $0.70 \mathrm{~m}$, obtained on 7 September 2007 in the final days of the ablation period (which in 2007 extended into September) under cloud-free conditions. The difference between the satellite-derived $\left(0.55 \mathrm{~km}^{2}\right)$ and ground-based $\left(0.56 \mathrm{~km}^{2}\right)$ surface areas of the glacier was $2 \%$, which was taken as an error due to the presence of snow along the glacier margins in both 2007 and 1979. This is likely to be an overestimation reflecting errors in mapping from a satellite image as well as the presence of snow, especially for 2007. The summer of 1979 was one of the coldest on record (see Fig. 7a further below), and although the extent of snow cover was low in mid-August when the survey was conducted (personal communication from V.M. Plyusnin, 2009), a $2 \%$ error is likely to be realistic.

The presence of debris cover on the glacier tongue is the most significant source of uncertainty, as debris cover masks transition between the glacier and the body of dead ice located in front of the glacier. A marginal hollow around the glacier snout, which is shallow on Azarova due to the very low ice flow velocities (Novikova and Grinberg, 1972), was used as an indicator of the glacier boundary. The same indicator was used in 1979 (personal communication from V.M. Plyusnin, 2009). The adoption of the same approach to the definition of glacier boundaries in 1979 and 2007 helped to minimize this uncertainty. However, potential errors in the 1979 delineation cannot be evaluated numerically from the available data. To account for them, an additional error of $2 \%$, based on our experience of repeated in situ mapping of debris-covered glacier tongues by different surveyors, was added to the 1979 area calculation. The total planimetric error was calculated as the root sum square of all the above terms and is $6.9 \%$.

Vertical precision of the 1979 map was estimated as $\pm 5 \mathrm{~m}$, which is the half-distance between the contours (Seymour, 1980). However, it is not the absolute elevations but consistency between the 1979 and 2007 DEMs that is important in calculating changes in glacier surface elevation (Cox and March, 2004; Thibert and others, 2008). A comparison of the elevations of the 1979 and 2007 DEM gridcells representing ice-free stable terrain produced $\mathrm{RMSE}_{z}$ of $\pm 1.8 \mathrm{~m}$. This value was taken as an error in the calculation of elevation change. The error in seasonality of thickness change related to the seasonal snow cover and firn on the glacier surface was negligible given the small extent of seasonal snow cover in August and the low amount of firn.

Sapiano and others (1998) and Elsberg and others (2001) estimated the uncertainty in geodetic mass-balance calculation due to the use of glacier-wide average density to be 5$6 \%$ for glaciers with snow, firn and ice in vertical profiles. A sensitivity test based on snow and firn covering $20 \%$ of the glacier surface and with an average firn layer depth of $3 \mathrm{~m}$ (both assumed values exceed the 2007 observations) showed that neglecting snow and firn densities on Azarova resulted in a $1 \%$ error in the calculation of the glacier-wide average density.

\section{Climate data}

The time series of air temperature and precipitation from the Chara meteorological station (Fig. 3) were used to evaluate the observed variations in regional climate. The air-temperature and precipitation time series started in 1938 and 1951, respectively. In addition to these data, a Campbell Scientific automatic weather station (AWS) was deployed on Azarova at 2280 ma.s.I. (Fig. 3) from 25 July to 13 August 2007, providing data on air temperature, incoming and outgoing short- and longwave radiation fluxes measured by GNR4 Kipp \& Zonen radiometer, and wind speed and wind direction every $15 \mathrm{~min}$. Due to a deficiency in the electric circuit of the AWS, the sonic ranger data were intermittent. However, ablation was measured daily by the stake method using a network of seven stakes installed along the vertical profile of the glacier.

In addition to meteorological observations, regional climate-change scenarios were generated using the Providing REgional Climates for Impact Studies (PRECIS) regional climate modelling (RCM) system based on the HadRM3P RCM. PRECIS is a hydrostatic model with a horizontal resolution of $25 \mathrm{~km}$. Its full details are given by Jones and others (2004). PRECIS (HadRM3P) has been successfully used in mountainous regions, demonstrating particularly robust performance in the Altai (Shahgedanova and others, 2010). Three integrations have been performed for two time slices: 1961-90 represents the 'baseline' climate and 20712100 is used for future climate-change projections for the A2 and $\mathrm{B} 2 \mathrm{CO}_{2}$ emission scenarios. These two scenarios assume increases in mean $\mathrm{CO}_{2}$ concentrations to 830 and 600 ppm by 2100, respectively (Nakiáenoviá and Swart, 2000). The model domain extent was $40.5-61.5^{\circ} \mathrm{N}, 67.5-$ $130.5^{\circ} \mathrm{E}$. Model output for the area $56.5-57.5^{\circ} \mathrm{N}, 117-$ $118.5^{\circ} \mathrm{E}$ was used in the analysis performed here.

Prior to the interpretation of regional climate-change scenarios, model output was validated against the data derived from CRU TS3 gridded datasets of observed air temperatures and precipitation intensities with a resolution of $0.5^{\circ}$ (Mitchell and Jones, 2005). In addition, validation was performed using data for the 1961-90 period from three meteorological stations (Chara; Bolshaya Leprinda $\left(56.6^{\circ} \mathrm{N}\right.$, $117.6^{\circ} \mathrm{E} ; 1001 \mathrm{~m}$ a.s.I.); and Nichatka $\left(57.4^{\circ} \mathrm{N}, 117.3^{\circ} \mathrm{E}\right.$; $561 \mathrm{~m}$ a.s.I.)) located in the selected domain. The gridded datasets incorporate data from the stations that were functioning intermittently in the region in the 1961-90 period (Mitchell and Jones, 2005). However, gridded temperature and precipitation data were not adjusted for altitude and, in this sense, the gridded datasets have little advantage over data from the individual stations, all of which are located in valleys. The average altitude of the 

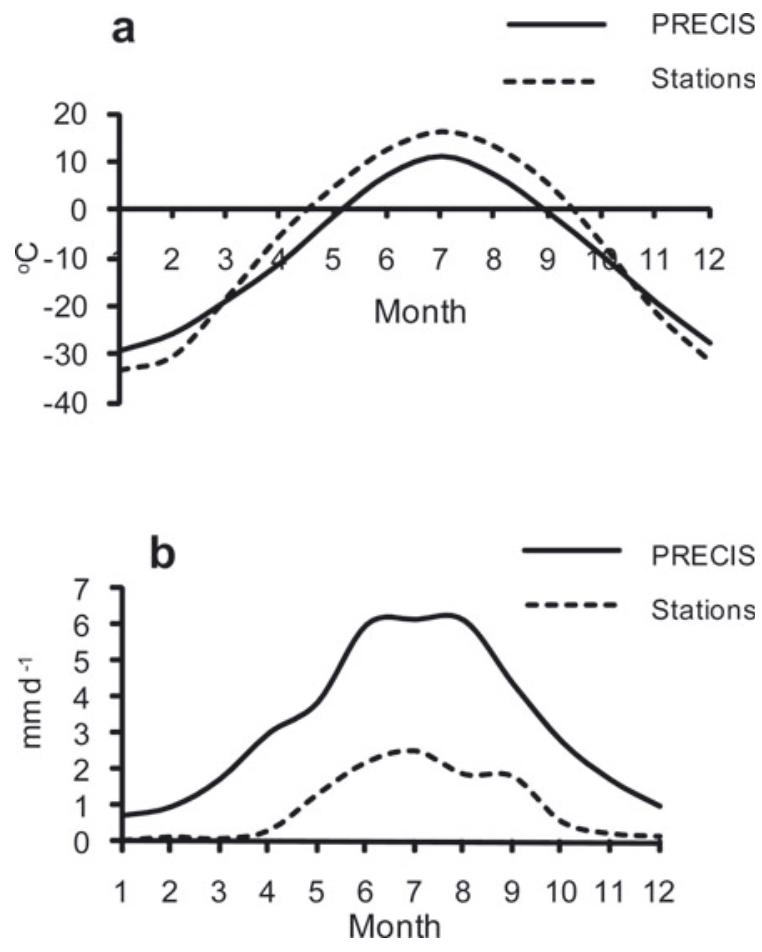

Fig. 4. Modelled versus observed mean monthly temperatures (a) and precipitation intensity (b) for 1961-90 for the Kodar mountains $\left(56.5-57.5^{\circ} \mathrm{N}, 117-118^{\circ} \mathrm{E}\right)$.

model validation domain was 1425 ma.s.l. The average altitude of the three stations was $758 \mathrm{~m}$ a.s.l.

The annual cycles of both air temperature and precipitation intensity are reproduced by the model (Fig. 4), and the differences in absolute values are mostly accounted for by the difference in altitude between the model domain elevation and station elevations. The monthly temperatures derived from the gridded datasets are in close agreement with the modelled data in summer, only exceeding the model by $0.6-1.7^{\circ} \mathrm{C}$ between April and September (Fig. 4a). The differences between the modelled and the station data are larger, at $4.7-5.7^{\circ} \mathrm{C}$, but this is largely due to the $667 \mathrm{~m}$ difference in altitude between the meteorological stations and the model domain, which accounts for $4^{\circ} \mathrm{C}$ under the average environmental lapse rate of $0.6^{\circ} \mathrm{C}(100 \mathrm{~m})^{-1}$. Between November and February, modelled temperatures exceed station temperatures by $2.2-4.7^{\circ} \mathrm{C}$ (Fig. 4a), in line with the persistent temperature inversions characteristic of the region (Shahgedanova, 2002). Validation of precipitation intensities in eastern Siberia is extremely difficult due to the absence of high-altitude stations and a considerable difference between the precipitation amounts received in valleys and at high elevations, especially in winter (Shahgedanova, 2002). The modelled precipitation intensities significantly exceed the observed intensities (Fig. 4b), but this difference is consistent with altitudinal precipitation gradients and with the short-term precipitation measurements conducted at high elevations in the 1950s-60s. In the Kodar and adjacent mountain ranges, Preobrazhensky (1960) and Novikova and Grinberg (1972) report annual precipitation totals of 600960 and $840-1200 \mathrm{~mm}$ in the 1000-1700 and 2000-2500 m elevation bands, respectively. The average annual precipitation total simulated by PRECIS is $1146 \mathrm{~mm}$. Our precipitation measurements conducted in July-August 2008 indicated that monthly precipitation totals measured near

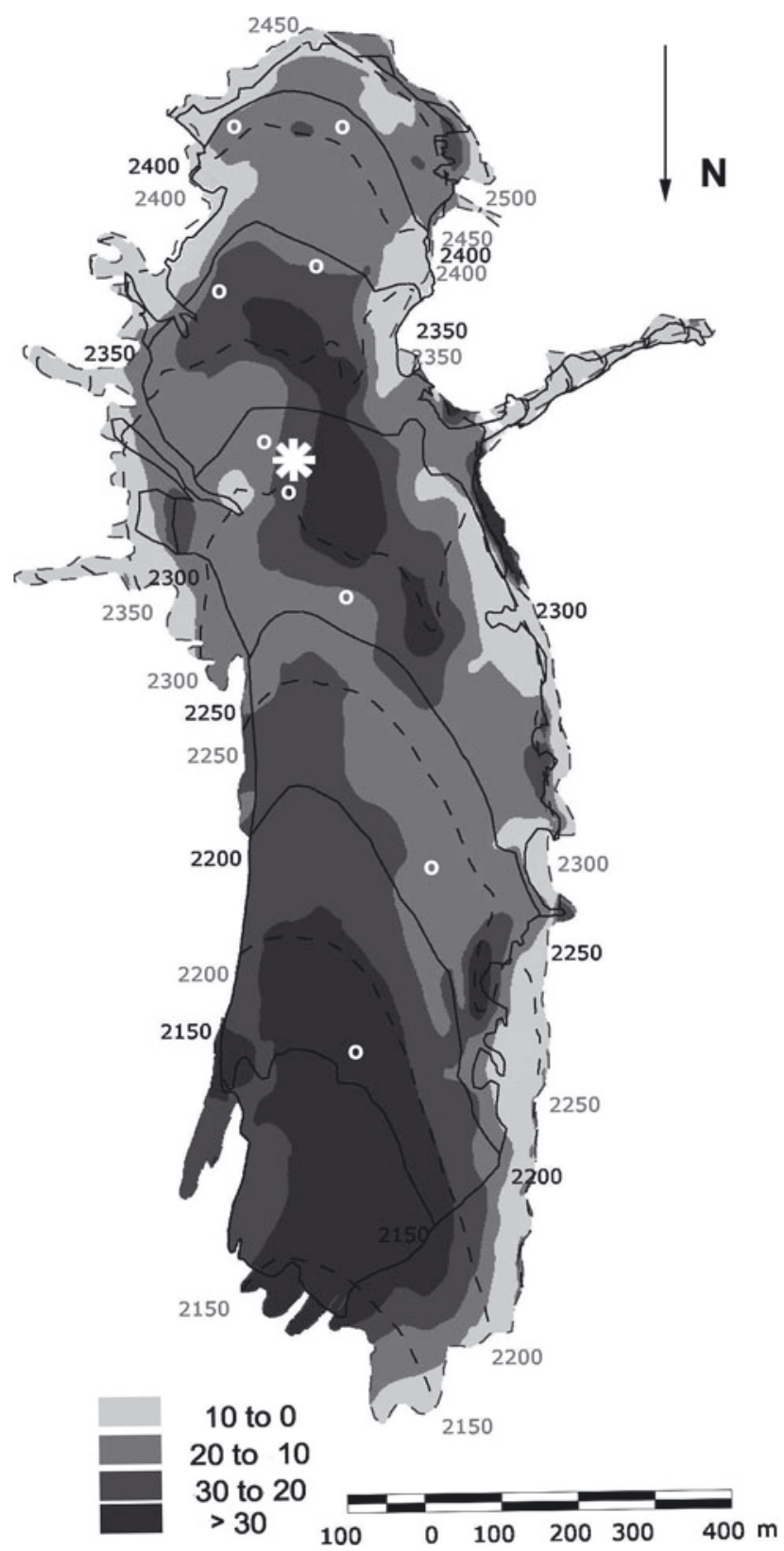

Fig. 5. Area and elevation $(\Delta h ; \mathrm{m})$ changes between 1979 (dashed lines; lettering in grey) and 2007 (solid lines; lettering in black). Star and dots denote positions of AWS and ablation stakes respectively.

Azarova glacier (at 2055 m a.s.I.) exceeded monthly precipitation totals at the Chara station by a factor of 2.7. This is consistent with an overestimation of station precipitation by PRECIS by a factor of 2.6.

\section{RESULTS}

The surface area of Azarova glacier decreased by $20 \%$ between 1979 and 2007 (Table 1) and, as expected, the retreat was observed predominantly at low elevations below $2200 \mathrm{~m}$ a.s.l. (Fig. 5). On average, the glacier thinned by $20 \pm 1.4 \mathrm{~m}$ between 1979 and 2007 or by $0.71 \mathrm{~m} \mathrm{a}^{-1}$. Importantly, lowering of the glacier surface has occurred not only on the glacier tongue but across the entire glacier (Figs 5 and 6). In the lowest $200 \mathrm{~m}$, surface lowering reached $40 \mathrm{~m}$, but even at the highest elevations over $2400 \mathrm{~m}$, the glacier surface lowered by $10-20 \mathrm{~m}$. The reduction in glacier 


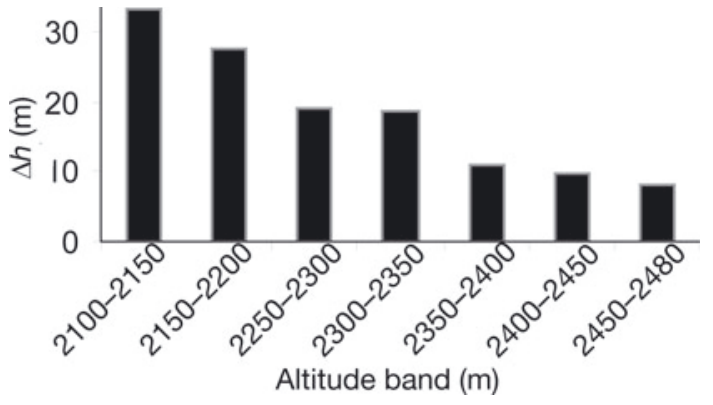

Fig. 6. Vertical profile of elevation changes of Azarova glacier (1979-2007)

surface area and its thinning has resulted in a decline in glacier volume of $0.016 \pm 0.002 \mathrm{~km}^{3}$. The cumulative areaweighted mass balance for the 1979-2007 period was $-18 \pm 1.6 \mathrm{~m}$ w.e., and the average mass balance was $-640 \pm 60 \mathrm{~mm}$ w.e. $\mathrm{a}^{-1}$.

Analysis of the climate records shows that while there is no statistically significant linear trend in the July-August (JA) temperature at the Chara station between 1938 and 2007, a step change in JA temperature occurred after 1980 (Fig. 7a). From 1938 to 1979 , the average JA temperature was $14.3^{\circ} \mathrm{C}$; from 1980 to 2007 , it was $15.3^{\circ} \mathrm{C}$. The difference between the means is statistically significant at the 0.05 confidence level. JA air temperature has been increasing since 1979 at a rate of $0.036^{\circ} \mathrm{Ca}^{-1}$ (Fig. 7a). Importantly, June temperature has been increasing since the early 1960 s at a rate of $0.05^{\circ} \mathrm{Ca}^{-1}$, suggesting a potential extension of the ablation season. There are no statistically significant long-term linear trends in either annual (Fig. 7b), September-May (not shown) or JA (Fig. 7C) precipitation, although there was a $9 \%$ increase in JA precipitation from the $1952-79$ to the 1980-2007 period, which is consistent with increasing air temperatures.

Not only the amount but also the occurrence and type of summer precipitation is an important control over glacier melt. An increase in air temperature limits the occurrence of snowfalls and enhances glacier sensitivity to warming due to the changing albedo of the glacier surface and, on cold glaciers, to additional heat flux supplied by rainfall (Fujita, 2008). During 2007 and 2008, albedo on Azarova glacier increased from an average of $26 \%$ to $>40 \%$ for $2-3$ days following snowfalls. Moreover, even when JA temperatures were close to the long-term average, three and five snowfalls were registered in 2007 and 2008 respectively, resulting in near-zero ablation for a total of 10-15 days of the 2 month ablation season.

Results of climate modelling show that in 2071-2100 the mean July and August temperatures are projected to increase
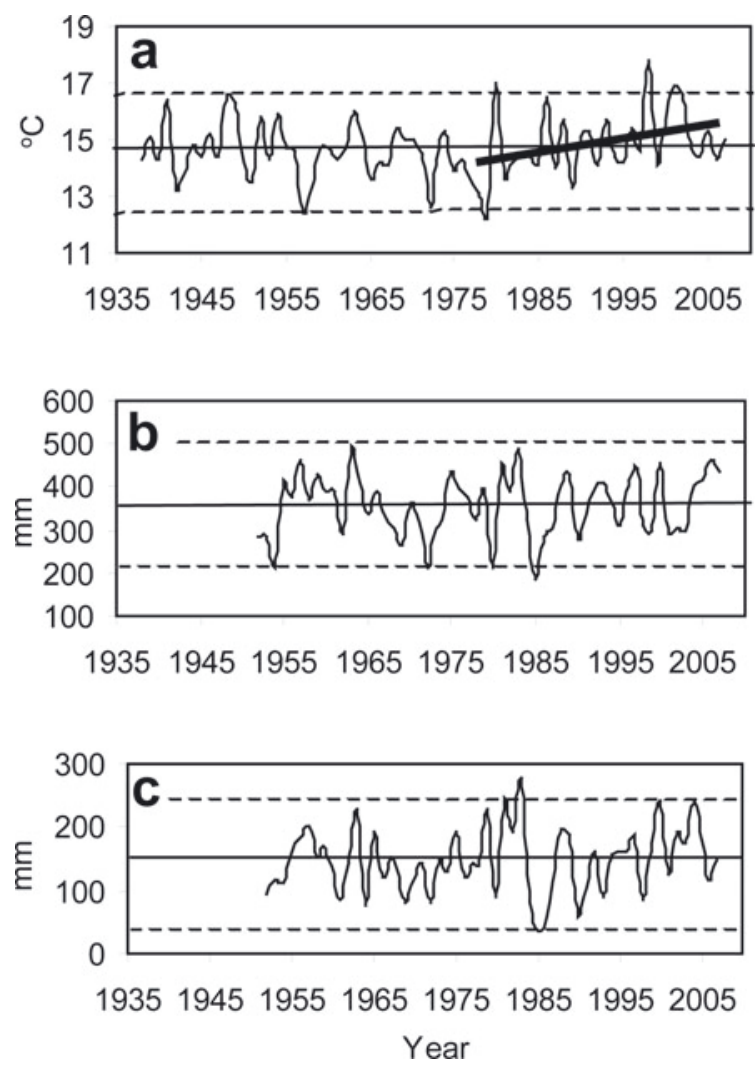

Fig. 7. Time series of (a) July-August (JA) air temperature, (b) annual precipitation and (c) JA precipitation at the Chara meteorological station. Thin solid lines show time-series averages; dashed lines show \pm two standard deviations from record means; bold solid line in (a) shows linear trend in JA air temperature for the 1979-2007 period.

by $3.2^{\circ} \mathrm{C}$ and $4.7^{\circ} \mathrm{C}$ under the $\mathrm{B} 2$ scenario, and by $4.9^{\circ} \mathrm{C}$ and $6.2^{\circ} \mathrm{C}$ under the more aggressive A2 scenario (Fig. 8a). Even under the moderate B2 scenario, the ablation season is projected to increase by 5-6 weeks. Annual precipitation totals will increase by $29 \%$ and $31 \%$ under the B2 and A2 scenarios, respectively (Fig. 8b). However, the total amounts of solid precipitation are projected to be quite different, increasing by $20 \%$ under the B2 scenario but declining by $3 \%$ under the A2 scenario. The proportion of summer snowfalls (June-August), however, will decline from the current $2-15 \%$ to $0-2 \%$ under the moderate B2 scenario (Fig. 8c). Liquid precipitation accounts for $17 \%$ and $26 \%$ of the total in May and September of the baseline period and will account for $22 \%$ and $40 \%$ under the B2 scenario (Fig. 8c). This statistic applies to an average altitude of the model domain that is $720 \mathrm{~m}$ below the current glacier tongue elevation. However, the projected shift from snowfall

Table 1. Changes in the characteristics of Azarova glacier

\begin{tabular}{|c|c|c|c|c|c|c|}
\hline \multirow[t]{3}{*}{ Year } & \multicolumn{2}{|c|}{ Altitude } & \multirow[t]{2}{*}{ Orthogonal surface area } & \multicolumn{3}{|c|}{ Lowering of glacier surface 1979-2007 } \\
\hline & Upper & Terminus & & Average & Max & Min \\
\hline & ma.m.s.l. & ma.m.s.l. & $\mathrm{km}^{2}$ & $\mathrm{~m}$ & $\mathrm{~m}$ & $\mathrm{~m}$ \\
\hline 1979 & 2493 & 2130 & 0.701 & 20.3 & 40 & 0 \\
\hline 2007 & 2480 & 2145 & 0.560 & & & \\
\hline
\end{tabular}


to rainfall is likely to affect Azarova glacier in July and August by limiting the ability of summer snowfalls to interrupt the ablation season; and in June and early September when more precipitation will occur as rain.

\section{DISCUSSION}

\section{Links between glacier change and climate}

The sensitivity of Azarova glacier mass balance to climatic warming is difficult to quantify due to the lack of continuous observations. Modelling studies suggest mass-balance sensitivity of $\sim 350 \mathrm{~mm}$ w.e. $\mathrm{a}^{-1}$ per $1^{\circ} \mathrm{C}$ warming for glaciers with a melt season of 60 days (Braithwaite and others, 2002), and $200 \mathrm{~mm}$ w.e. $\mathrm{a}^{-1}$ for glaciers with the continentality index of 50 (de Woul and Hock, 2005), which are characteristic of Azarova. Estimation of mass-balance sensitivity for a $1^{\circ} \mathrm{C}$ temperature increase and $10 \%$ precipitation increase proposed by Oerlemans (1993) yields a sensitivity of $-390 \mathrm{~mm}$ w.e. for the annual precipitation, exceeding that observed at the Chara station in 1979-2007 by a factor of 2.6, and is consistent with the PRECIS simulation of precipitation intensities at higher altitudes during the baseline period. The assessments by Braithwaite and others (2002) and de Woul and Hock (2005), however, refer to subpolar glaciers and those located north of $60^{\circ} \mathrm{N}$, and these generally experience lower summer temperatures. In JulyAugust 2008, incoming solar radiation on Azarova averaged $243 \mathrm{~W} \mathrm{~m}^{-2}$, daytime net radiation was $178 \mathrm{~W} \mathrm{~m}^{-2}$ and daily mean air temperature was $6.4^{\circ} \mathrm{C}$, which is comparable with meteorological conditions on temperate glaciers (e.g. in the European Alps (Oerlemans and others, 2009) and in the Caucasus (Shahgedanova and others, 2007)). Daily ablation rates were $20-50 \mathrm{~mm}$ w.e. $\mathrm{d}^{-1}$ for snow and 20-90 mm w.e. $\mathrm{d}^{-1}$ for ice. This occurred under temperatures close to the long-term average and indicates glacier melt more typical of temperate glaciers. Preobrazhensky (1960) reports similar values for the summers of 1958 and 1959. Oerlemans (1993) explains the higher sensitivity of glaciers located in wetter regions as being a consequence of the lower elevations of glacier tongues and, consequently, higher temperatures. Azarova glacier (as well as other glaciers in the Kodar) is positioned at low elevations, and thus experiences comparatively high net radiation and air temperatures in summer. Its strongly negative mass balance indicates high sensitivity to climatic warming, enhanced by a diminishing fraction of snowfall in the warm season, and a limited compensating effect of cold-season precipitation.

Future climate projections indicate a strong warming in July-August under the moderate B2 and aggressive A2 scenarios (Fig. 8a). Importantly, June temperatures will increase by $2.6^{\circ} \mathrm{C}$ and $4.7^{\circ} \mathrm{C}$ under these two scenarios, resulting in positive temperatures at the glacier tongue altitude. Furthermore, September temperatures will increase by $4.4^{\circ} \mathrm{C}$ and $5.9^{\circ} \mathrm{C}$ (Fig. 8a) and these shifts will affect the length of the ablation season which will extend into June and the first half of September. The annual amount of solid precipitation will increase relative to the baseline period under the B2 scenario by $20 \%$. This increase is projected for October-May, and half of it will occur in three months: April, early May, and October. Under the A2 scenario, an $8 \%$ increase in solid precipitation will occur between November and March, but cold-season precipitation will remain relatively low, with monthly totals of $42-78 \mathrm{~mm}$.
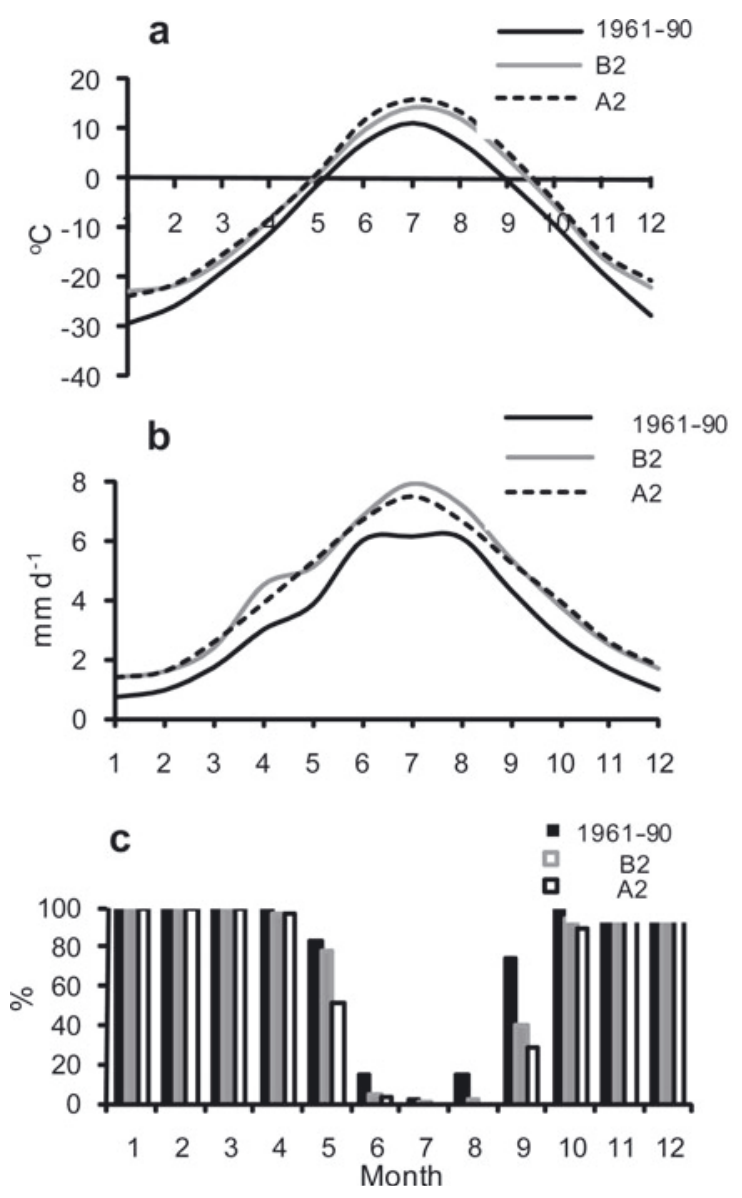

Fig. 8. The regional air temperature (a), precipitation intensity (b) and solid precipitation fraction (c) scenarios for the Kodar mountains $\left(56.5-57.5^{\circ} \mathrm{N}, 117-118^{\circ} \mathrm{E}\right)$.

A decline in solid precipitation projected for May, June and September will result in a decrease in the annual solid precipitation total by $3 \%$. The difference between projected trends for solid precipitation, resulting from different rates of warming, is an important finding because of its potential impacts on future glacier change. Results of previous modelling studies suggest that a $20 \%$ increase in annual solid precipitation does not compensate the impacts of $3-5^{\circ} \mathrm{C}$ warming on glaciers gaining mass though snow accumulation (Oerlemans, 1993; Braithwaite and others, 2002). However, the impact of such a warming on glaciers that predominantly gain mass through refreezing requires further investigation.

\section{Comparison to other Siberian regions}

The observed $20 \pm 6.9 \%$ shrinkage of Azarova between 1979 and 2007 is in line with an average shrinkage of similar-sized $\left(0.5-1 \mathrm{~km}^{2}\right)$ glaciers in the Russian Altai (Shahgedanova and others, 2010). The small Altai glaciers lost $28 \pm 6 \%$ of their surface area between 1952 and 2004, but analysis of ground-based measurements of glacier front fluctuations confirmed that most of this retreat occurred after the mid-1970s (Shahgedanova and others, 2010). From 1979 to 2007, the average glaciological mass balances of Maliy Aktru and Leviy Aktru, in the Altai, were -95 and $-133 \mathrm{~mm}$ w.e. $\mathrm{a}^{-1}$, respectively (WGMS, 2007 and earlier volumes). Geodetic and glaciological mass-balance measurements are subject to different instrumental and physical biases (Cogley, 2009), but these are likely to be smaller than 
the observed differences between these regions. Indeed, most of the difference between the strongly negative mass balance of Azarova and the Aktru glaciers is likely to result from the higher elevation of the Aktru glaciers (20004000 m a.s.l.).

In another glaciated Siberian massif, the Suntar-Khayata, glaciers lost $19 \%$ of their surface area between 1957 and 2003 (Ananicheva, 2006). This rate of glacier wastage appears to be more comparable to Azarova, but it is possible that results for the Suntar-Khayata are overestimated due to use of the 1957 WGI data. The use of the WGI data was previously found to result in an overestimation of glacier shrinkage in different regions (e.g. by $5 \%$ in the Altai (Shahgedanova and others, 2010) and by $16 \%$ in the Polar Urals (ongoing analysis)). Indeed, the 1963 area of Azarova is reported by the WGI as $1.3 \mathrm{~km}^{2}$ including the area of dead ice located in front of the glacier (Novikova and others, 1972). A slower rate of glacier shrinkage in the SuntarKhayata is suggested by other measurements. For example, glacier thinning on glacier no. 31 averaged $10 \mathrm{~m}$ for the 1957-2003 period, where the mass balance was estimated at $-206 \mathrm{~mm}$ w.e. $\mathrm{a}^{-1}$ (Ananicheva, 2006), i.e. three times lower than the average mass balance of Azarova glacier in 19792007. Even slower glacier wastage of glacier surface area was reported in the Buordakh massif of the Chersky mountains by Gurney and others (2008). There, the extent of 80 glaciers was measured and it was reported that $38 \%$ have not undergone a measurable retreat since 1850, although most glaciers exhibited signs of downwasting (Gurney and others, 2008). Glaciers of both the Suntar-Khayata mountains $\left(61.5-63^{\circ} \mathrm{N}, 139-143^{\circ} \mathrm{E}\right)$ and Buordakh massif $\left(65^{\circ} 12^{\prime} \mathrm{N}\right.$, $\left.145^{\circ} 56^{\prime} \mathrm{E}\right)$ are located further north and at higher elevations (extending to 2800-3000 ma.s.l.) than Azarova. They are therefore exposed to lower summer temperatures, as indicated by continuous observations at the regular meteorological stations (Shahgedanova, 2002) and by episodic observations in the glaciated areas (Ananicheva, 2006).

\section{CONCLUSIONS}

The cold-based glaciers of Siberia have received little attention in the literature, partly due to their remote location and partly due to the notion that they are less sensitive to climatic perturbations compared to more maritime glaciers (Dyurgerov and Meier, 2000; Braithwaite and others, 2002). However, analyses of changes in area and volume and calculations of geodetic mass balance of Azarova glacier appear to question this latter assumption. Our results have shown that this glacier responded strongly to a $1{ }^{\circ} \mathrm{C}$ increase in summer temperatures between 1979 and 2007. The surface area of the glacier declined by $20 \pm 6.9 \%$ and surface lowering occurred across the whole glacier, averaging $20 \pm 1.8 \mathrm{~m}$. This resulted in a strongly negative mass balance of $640 \pm 60 \mathrm{~mm}$ w.e. $\mathrm{a}^{-1}$.

Azarova glacier, in common with other glaciers in this region, is located in a deep valley, has a northerly aspect and receives significant avalanche nourishment. Given these topographic characteristics and the short ablation season interrupted by snowfalls, these glaciers are likely to be better 'protected' from climate warming, compared to other glaciers that may be more exposed. However, the strongly negative mass balance of Azarova and its significant downwasting, even at its highest elevations, suggest that these local effects do not counteract the impacts of increasing summer temperatures and declining solid precipitation. Future climate projections indicate that by 2071-2100, summer temperatures will increase by $3-6^{\circ} \mathrm{C}$ compared with the 1961-90 period. This is likely to represent a serious challenge to glacier viability within the 21 st century, although this will also depend on future changes in solid precipitation, which are more uncertain than temperature. As such, modelling the sensitivity of Azarova glacier mass balance to climatic warming and to increases in solid precipitation projected under the moderate B2 scenario is planned as a next step in this research.

\section{ACKNOWLEDGEMENTS}

We are grateful to V.M. Plyusnin (Irkutsk Institute of Geography, Russian Academy of Sciences) for providing data of the 1979 survey and the unpublished map of Azarova glacier. This work has been conducted as part of the project 'Evaluating Recent and Future Climate Change and Glacier Dynamics in the Mountains of Southern Siberia' supported by EU INTAS grant No. 1000013-8593 and project No. 3271.2010.5 of the Leading Scientific Schools of Russia programme.

\section{REFERENCES}

Ananicheva, M.D. 2006. Gory Cherskogo i Suntar-Khayta. [The Chersky and Suntar-Khayata Mountains]. In Kotlyakov, V.M., ed. Oledenenie severnoi $i$ tsentral'noi Evrazii $v$ sovremennuju epochu [Contemporary glaciation in northern and central Eurasia]. Moscow, Nauka, 198-204. [In Russian.]

Andreassen, L.M. 1999. Comparing traditional mass balance measurements with long-term volume change extracted from topographical maps: a case study of Storbreen glacier in Jotunheimen, Norway, for the period 1940-1997. Geogr. Ann., 81A(4), 467-476.

Arendt, A.A., K.A. Echelmeyer, W.D. Harrison, C.S. Lingle and V.B. Valentine. 2002. Rapid wastage of Alaska glaciers and their contribution to rising sea level. Science, 297(5580), 382-386.

Barry, R.G. 2006. The status of research on glaciers and global glacier recession: a review. Progr. Phys. Geogr., 30(3), 285-306.

Bauder, A., M. Funk and M. Huss. 2007. Ice-volume changes of selected glaciers in the Swiss Alps since the end of the 19th century. Ann. Glaciol., 46, 145-149.

Braithwaite, R.J., Y. Zhang and S.C.B. Raper. 2002. Temperature sensitivity of the mass balance of mountain glaciers and ice caps as a climatological characteristic. Z. Gletscherkd. Glazialgeol., 38(1), 35-61.

Cogley, J.G. 2009. Geodetic and direct mass-balance measurements: comparison and joint analysis. Ann. Glaciol., 50(50), 96-100.

Cox, L.H. and R.S. March. 2004. Comparison of geodetic and glaciological mass-balance techniques, Gulkana Glacier, Alaska, U.S.A. J. Glaciol., 50(170), 363-370.

De Woul, M. and R. Hock. 2005. Static mass-balance sensitivity of Arctic glaciers and ice caps using a degree-day approach. Ann. Glaciol., 42, 217-224.

Dyurgerov, M.B. and M.F. Meier. 2000. Twentieth century climate change: evidence from small glaciers. Proc. Natl. Acad. Sci. USA (PNAS), 97(4), 1406-1411.

Elsberg, D.H., W.D. Harrison, K.A. Echelmeyer and R.M. Krimmel. 2001. Quantifying the effects of climate and surface change on glacier mass balance. J. Glaciol., 47(159), 649-658.

Fujita, K. 2008. Effect of precipitation seasonality on climatic sensitivity of glacier mass balance. Earth Planet. Sci. Lett., 276(1-2), 14-19. 
Fujita, K. and Y. Ageta. 2000. Effect of summer accumulation on glacier mass balance on the Tibetan Plateau revealed by massbalance model. J. Glaciol., 46(153), 244-252.

Granshaw, F.D. and A.G. Fountain. 2006. Glacier change (19581998 ) in the North Cascades National Park Complex, Washington, USA. J. Glaciol., 52(177), 251-256.

Gurney, S.D., V.V. Popovnin, M. Shahgedanova and C.R. Stokes. 2008. A glacier inventory for the Buordakh Massif, Cherskiy Range, north east Siberia, and evidence for recent glacier recession. Arct. Antarct. Alp. Res., 40(1), 81-88.

Jones, R.G. and 6 others. 2004. Generating high resolution climate change scenarios using PRECIS. Exeter, Meteorological Office. Hadley Centre for Climate Prediction and Research.

Kadota, T. and D. Gombo. 2007. Recent glacier variations in Mongolia. Ann. Glaciol., 46, 185-188.

Mitchell, T.D. and P.D. Jones. 2005. An improved method of constructing a database of monthly climate observations and associated high-resolution grids. Int. J. Climatol., 25(6), 693-712.

Nakiáenoviá, N. and R. Swart, eds. 2000. Emissions scenarios: a special report of Working Group III of the Intergovernmental Panel on Climate Change. Cambridge, etc., Cambridge University Press.

Novikova, Z.S. and A.M. Grinberg, eds. 1972. Katalog lednikov SSSR, Tom 17: Leno-Indigirskyi rayon. Vypusk 2, Chast' 1 Basseiny rek Chary $i$ Vitima. [Catalogue of glaciers of the USSR, Volume 17: The Lena-Indigirka region. No. 2, Part 1, Catchments of the Rivers Chara and Vitim]. Leningrad, Gidrometeoizdat. [In Russian.]

Oerlemans, J. 1993. Modelling of glacier mass balance. In Peltier, W.R., ed. Ice in the climate system. Berlin, etc., Springer-Verlag, 101-116. (NATO ASI Series I: Global Environmental Change 12.)

Oerlemans, J., R.H. Giesen and M.R. van den Broeke. 2009. Retreating alpine glaciers: increased melt rates due to accumulation of dust (Vadret da Morteratsch, Switzerland). J. Glaciol., 55(192), 729-736

Panagiotopoulos, F., M. Shahgedanova, D.B. Stephenson and A. Hannachi. 2005. Observed trends and teleconnections of the Siberian high: a recently declining center of action. J. Climate, 18(9), 1411-1422.

Preobrazhenskiy, V.S. 1960. Kodarskiy lednikovyy rayon (Zabaykal'ya) [The Kodarsky glacier region (Transbaikal)]. Moscow, Nauka. Akademiia Nauk SSSR. [In Russian with English summary.]

Sapiano, J.J., W.D. Harrison and K.A. Echelmeyer. 1998. Elevation, volume and terminus changes of nine glaciers in North America. J. Glaciol., 44(146), 119-135.

Seymour, W.A. 1980. A history of the Ordnance Survey. Folkestone, Dawson.

Shahgedanova, M. 2002. Climate at present and in the historical past. In Shahgedanova, M., ed. The physical geography of northern Eurasia. Oxford, etc., Oxford University Press, 70-102.

Shahgedanova, M., V. Popovnin, A. Alaynikov, D. Petrakov and C.R. Stokes. 2007. Long-term change, interannual and intraseasonal variability in climate and glacier mass balance in the central Greater Caucasus, Russia. Ann. Glaciol., 46, 355-361.

Shahgedanova, M., G. Nosenko, T. Khromova and A. Muraveyev. 2010. Glacier shrinkage and climatic change in the Russian Altai from the mid-20th century: an assessment using remote sensing and PRECIS regional climate model. J. Geophys. Res., 115(D16), D16107. (10.1029/2009JD012976.)

Solomina, O.N. 2000. Retreat of mountain glaciers of northern Eurasia since the Little Ice Age maximum. Ann. Glaciol., 31, 26-30.

Thibert, E., R. Blanc, C. Vincent and N. Eckert. 2008. Glaciological and volumetric mass-balance measurements: error analysis over 51 years for Glacier de Sarennes, French Alps. J. Glaciol., 54(186), 522-532.

World Glacier Monitoring Service (WGMS). 2007. Glacier Mass Balance Bulletin No. 9 (2004-2005), eds. Haeberli, W., M. Hoelzle and M. Zemp. ICSU(FAGS)/IUGG(IACS)/UNEP/ UNESCO/WMO, World Glacier Monitoring Service, Zürich.

Zemp, M. and 6 others. 2010. Reanalysis of multi-temporal aerial images of Storglaciären, Sweden (1959-99). Part 2: Comparison of glaciological and volumetric mass balances. Cryosphere, 4(3), 345-357. 